\title{
Martin M. Melosi, Precious commodity. Providing water for America's cities
}

\author{
University of Pittsburgh Press, Pittsburgh, 2011, \\ ISBN 9780822961413, 304 pages (with Index)
}

\author{
Maurits W. Ertsen
}

Received: 16 August 2011/Accepted: 18 August 2011/Published online: 3 September 2011

(C) The Author(s) 2011. This article is published with open access at Springerlink.com

There are people who argue that history teaches us lessons. Some may even go as far as stating that our future societal directions can be detected from the past. In his latest book Precious Commodity, Martin Melosi does plead guilty for "trying to connect pressing current environmental issues with their past histories" (p.XI). However, unlike others, Melosi's way of doing "history in the moment" (p.XI) does neither hide the contested nature of water nor does it presume that one simple linear trajectory explains our own times. No big certainties for Melosi. Instead, his examination of public versus private water control shows the complexity of water resources development and management.

Precious Commodity is a collection of both previously published research and a few new chapters. After an introduction to the theme, we read about the many river projects in America, about water supply and sewerage in American cities in the nineteenth and twentieth centuries, and we are introduced to some case studies on public and private water in the cities of San Jose and Houston. I must confess that when reading it I could not help asking myself at times how-and why - these particular chapters would shape a coherent discussion on private and public water resources management and development. Furthermore, despite the work Melosi put in limiting duplications in the chapters, there are still some left in the book, especially in the chronology of water infrastructure development in American cities. I did like the introductions to the chapters, explaining where the particular chapter comes from and what its position in the book is.

Having said that, the individual chapters are interesting to read and do give plenty of useful information and observations on water development and its many facets in the United States, especially on decisions on water control, and on the many reasons for and interests in water projects that interact. Going from the general and the national, the case chapters provide historical details and analysis, which serve as input for the more general concluding chapters on the issue of "the public versus the private" in water management. It is in the final chapters (especially seven, eight, and the conclusions) that the book really comes alive, especially because Melosi goes further in showing that the choices between

M. W. Ertsen $(\bowtie)$

Water Resources Management, Department of Civil Engineering and Geosciences, Delft University of Technology, Delft Stevinweg 1, P.O. Box 5048 2600, GA, Delft, The Netherlands

e-mail: m.w.ertsen@tudelft.nl

URL: www.wrm.tudelft.nl 
public or private in history depended on so many context-dependent factors. Obviously, such a conclusion would be correct, but indeed also rather obvious, even though the political debate in the last decades still shows that many believe in the exclusiveness of either model-just take a look at the available World Water Forum websites.

The many people who all think we have to make an exclusive choice between public and private should read Precious Commodity, because Melosi argues convincingly that the choice between public and private is misleading: "the idea that municipalities operate with pure public or private systems defies the evidence" (p. 199). The private and the public are intertwined. This is definitely a very political statement, but at least it is one that makes the "questions of control [...] a great deal messier" (p. 199). Those studying histories of water know that the combination of water, human actions, and their environments becomes messy very quickly; water history needs to deal with and show this messiness. In the end, this is a book about messiness. It is also a book showing that there is a water historian in many of us, although it may take a while to recognize oneself as such!

Open Access This article is distributed under the terms of the Creative Commons Attribution Noncommercial License which permits any noncommercial use, distribution, and reproduction in any medium, provided the original author(s) and source are credited. 